\title{
LAHAN PERTANIAN ABADI (LPA) DI KABUPATEN TANGERANG
}

\author{
Yunita Ismail \\ President University, Jababeka Education Park, \\ Jln. Kihajar Dewantara Kota Jababeka, \\ Bekasi 17550, Indonesia \\ yunitaismail@yahoo.co.id
}

\begin{abstract}
Tangerang regency is a supporting area for DKI Jakarta. The main function of this supporting area is as the human resource for fulfilling development needs of DKI Jakarta. Based on agricultural products from Tangerang regency, it is known that rice production almost 12 tons GKP/ha/year. This production is big enough to support harvest production nationally. Therefore, changing in dedicated agricultural field to be a nonagricultural area is considered will decrease rice production in Tangerang regency. Based on those conditions, it is needed to decide agricultural field which will not be used for non-agricultural activities, or so called agricultural land conversion (LPA). This research uses secondary data from Biro Pusat Statistik (Indonesia bureau of statistic) in Tangerang regency. The conclusion is that controlling the agricultural land conversion based on land capability survey in LPA area, as detail survey to irrigated rice field, non-irrigated rice field, and deep observation for agricultural field non-rice field.
\end{abstract}

Keywords: LPA (agricultural land conversion), Tangerang, agricultural, rice production

\begin{abstract}
ABSTRAK
Kabupaten Tangerang merupakan daerah penyangga bagi DKI Jakarta. Fungsi daerah penyangga yang paling utama adalah sebagai sumber tenaga kerja untuk memenuhi kebutuhan pembangunan DKI Jakarta. Dilihat dari hasil pertanian dari Kabupaten Tangerang, didapat bahwa produksi padi mencapai 12 ton GKP/ha/tahun. Produksi ini cukup besar untuk menunjang produksi panen secara nasional. Karenanya, perubahan peruntukan lahan pertanian menjadi untuk non pertanian dikhawatirkan akan menurunkan produksi padi di Kabupaten Tangerang. Dengan memperhatikan kondisi di atas, maka dirasa perlu untuk menentukan lahan pertanian yang tidak akan diubah peruntukkan untuk keperluan selain pertanian, atau disebut sebagai lahan pertanian abadi (LPA). Dalam penelitian ini, dipergunakan data sekunder yang berasal dari Biro Pusat Statistik Kabupaten Tangerang. Simpulan yang didapatkan yaitu pengelolaan LPA ditentukan berdasarkan survei kemampuan lahan sesuai dengan perwilayahan LPA, yaitu survei detil untuk lahan sawah beririgasi, survei semi detil untuk lahan sawah bukan irigasi, dan survei tinjauan mendalam untuk lahan pertanian bukan sawah.
\end{abstract}

Kata kunci: LPA (lahan pertanian abadi), Tangerang, pertanian, produksi padi 


\section{PENDAHULUAN}

\section{Latar Belakang}

Kabupaten Tangerang merupakan daerah penyangga bagi DKI Jakarta. Fungsi daerah penyangga yang paling utama adalah sebagai sumber tenaga kerja untuk memenuhi kebutuhan pembangunan DKI Jakarta. Paling sedikit terdapat 4 (empat) kecamatan yang berperan besar sebagai penyangga DKI Jakarta, yaitu Serpong, Pamulang, Ciputat dan Pondok Aren. Kebutuhan lahan untuk bangunan (baik perumahan maupun untuk industri) pada keempat kecamatan ini diperkirakan yang paling luas dibandingkan wilayah kecamatan di lingkungan Kabupaten Tangerang yang lain.

Berdasarkan SK Bupati No. 050/Kep-UM/2003 tentang titik berat pembangunan berdasarkan perwilayahan, wilayah Kabupaten Tangerang memiliki 4 (empat) kelompok wilayah. Wilayah Utara terdiri dari 8 (delapan) kecamatan, yaitu Kresek, Kronjo, Mauk, Kemiri, Sukadiri, Pakuhaji, Teluknaga dan Kosambi. Wilayah Selatan terdiri dari 7 (tujuh) kecamatan, yaitu Pagedangan, Serpong, Cisauk, Pamulang, Ciputat dan Pondok Aren. Wilayah Barat terdiri dari 5 (lima) kecamatan, yaitu Tigaraksa, Balaraja, Jayanti, Jambe dan Cisoka. Wilayah Tengah terdiri dari 6 (enam) kecamatan, yaitu Pasar Kemis, Panongan, Rajeg, Curug, Legok, Cikupa dan Sepatan. Pembagian wilayah Kabupaten Tangerang dalam 4 (empat) kelompok wilayah juga didasarkan atas keunggulan suatu wilayah dalam kaitan dengan titik berat pembangunan wilayah. Perwilayahan pembangunan membuat kebijakan pembangunan pada suatu wilayah lebih focus berdasarkan keunggulan wilayah yang bersangkutan. Sinergi pembangunan antar wilayah akan terjadi jika masing-masing wilayah dapat tumbuh dan berkembang berdasarkan potensi dan keunggulan yang dimiliki oleh masing-masing wilayah.

Kalau diperhatikan pertambahan jumlah penduduk di Kabupaten Tangerang cukup tinggi (dengan pertumbuhan penduduk 2 persen/tahun). Hal ini sesuai dengan peran Tangerang sebagai penyangga Jakarta. Akan tetapi dilain sisi, peruntukan lahan di Kabupaten Tangerang 63 persen untuk lahan pertanian (baik sawah maupun bukan sawah). Dari 2 hal di atas dapat diperkirakan bahwa perubahan peruntukan lahan dari pertanian ke non pertanian akan menjadi hal yang sering terjadi. Kalau dilihat dari hasil pertanian dari Kabupaten Tangerang, didapat bahwa produksi padi mencapai 12 ton GKP/ha/tahun. Produksi ini cukup besar untuk menunjang produksi panen secara nasional. Oleh karena itu perubahan peruntukan lahan pertanian menjadi untuk non pertanian dikhawatirkan akan menurunkan produksi padi di Kabupaten Tangerang. Dengan memperhatikan kondisi diatas, maka dirasa perlu untuk menentukan lahan pertanian yang tidak akan dirubah peruntukkan untuk keperluan selain pertanian, atau disebut sebagai lahan pertanian abadi (LPA).

\section{Rumusan Masalah}

Dari latar belakang di atas, dapat dilihat bahwa permasalahan yang dihadapi adalah (1) bagaimana menentukan lahan pertanian abadi di Kabupaten Tangerang; (2) bagaimana pengelolaan lahan pertanian abadi di Kabupaten Tangerang.

\section{Tujuan Penelitian}

Adapun tujuan dari penelitian ini adalah (1) untuk menentukan kriteria yang akan digunakan dalam menentukan lahan pertanian abadi di Kabupaten Tangerang; (2) untuk mendapatkan cara pengelolaan lahan pertanian abadi di Kabupaten Tangerang. 


\section{METODE PENELITIAN}

Dalam penelitian ini, dipergunakan data sekunder yang berasal dari Biro Pusat Statistik Kabupaten Tangerang. Adapun data yang dikumpulkan adalah data luas lahan sesuai dengan peruntukannya, data jumlah penduduk dan kepadatan penduduk, data tata guna lahan, data curah hujan dan debit sungai.

\section{HASIL DAN PEMBAHASAN}

\section{Gambaran Sektor Pertanian di Kabupaten Tangerang}

Untuk dapat mengidentifikasi faktor-faktor yang mempengaruhi penetapan lahanpertanian abadi dan parameter-parameter yang berpengaruh terhadap LPA, maka diperlukan data dan informasi mengenai: (1) statistik kependudukan dan pertanian dari Biro Pusat Statistik Kabupaten Tangerang; (2) statistik pengamatan curah hujan dan aliran sungai dari Dinas Bina Marga Kabupaten Tangerang; (3) peta batas administratif pemerintahan, tataguna lahan, DAS, jaringan jalan dan irigasi dari berbagai instansi yang terkait.

\section{Perwilayahan dan Demografi}

Luas lahan dan jumlah penduduk Kabupaten Tangerang disajikan dalam Tabel 1. Dari Tabel 1 tersebut tampak bahwa Wilayah Utara dan Tengah merupakan wilayah terluas, berturut-turut seluas $340,7 \mathrm{Km}^{2}$ dan 322,2 $\mathrm{Km}^{2}$. Sedangkan Wilayah Selatan merupakan wilayah dengan jumlah penduduk terbanyak, yaitu 1,2 juta orang pada tahun 2006. Dengan demikian Wilayah Selatan juga menjadi wilayah terpadat penduduknya yaitu 5.206 orang $/ \mathrm{Km}^{2}$, jauh di atas kepadatan rata-rata Kabupaten Tangerang Tahun 2006 sebanyak 3.151 orang $/ \mathrm{Km}^{2}$.

Tabel 1 Luas Lahan, Jumlah, Kepadatan, dan Laju Pertumbuhan Penduduk Tahun 2003-2006

\begin{tabular}{|c|c|c|c|c|c|c|c|}
\hline \multirow[t]{2}{*}{ No } & \multirow[t]{2}{*}{ Wilayah } & \multirow[t]{2}{*}{ Luas (Km2) } & \multicolumn{2}{|c|}{ Jumlah Penduduk (orang) } & \multicolumn{2}{|c|}{$\begin{array}{l}\text { Kepadatan Penduduk } \\
\text { (orang/Km2) }\end{array}$} & \multirow{2}{*}{$\begin{array}{c}\text { Pertumbuhan } \\
\text { Penduduk } \\
(\% / \text { thn })\end{array}$} \\
\hline & & & 2003 & 2006 & 2003 & 2006 & \\
\hline & Utara & 340,7 & 646.823 & 700.417 & 1.898 & 2.056 & 2,69 \\
\hline & Selatan & 221,9 & 1.088 .320 & 1.155 .333 & 4.904 & 5.206 & 2,01 \\
\hline & Barat & 205,4 & 441.157 & 478.378 & 2.148 & 2.329 & 2,74 \\
\hline & Tengah & 322,2 & 1.019 .437 & 1.101 .077 & 3.164 & 3.418 & 2,60 \\
\hline & Jumlah & $1.090,2$ & 3.195 .737 & 3.435 .205 & 2.931 & 3.151 & 2,44 \\
\hline
\end{tabular}

Sumber: BPS, 2007 (diolah)

Wilayah Barat Kabupaten Tangerang memiliki tingkat pertumbuhan penduduk tertinggi selama tahun 2003-2006 yaitu 2,74\% per tahun. Sedangkan Wilayah Selatan mengalami tingkat pertumbuhan penduduk yang paling rendah yaitu 2,01\% per tahun. Secara umum, rata-rata tingkat pertumbuhan penduduk Kabupaten Tangerang selama tahun 2003-2006 adalah 2,44\% per tahun. 


\section{Tataguna Lahan}

Wilayah Kabupaten Tangerang terdiri atas 40,7 ribu ha lahan sawah, sedangkan 68,3 ribu ha merupakan lahan kering. Wilayah Utara merupakan satu-satunya wilayah di Kabupaten Tangerang yang didominasi oleh lahan sawah, yaitu 21,1 ribu ha dari total Wilayah Utara seluas 34,1 ribu ha. Tabel 2 menyajikan tataguna lahan Kabupaten Tangerang Tahun 2006.

Sektor pertanian dalam arti luas (termasuk peternakan dan perikanan) meliputi 68,9 ribu ha, yang terdiri dari 40,7 ribu ha lahan sawah, 28,162 ribu ha merupakan lahan pertanian kering. Wilayah Selatan memiliki lahan pertanian terkecil di Kabupaten Tangerang. Wilayah Barat memiliki lahan sawah bukan irigasi (termasuk sawah tadah hujan dan pasang surut) yang terluas di Kabupaten Tangerang yaitu 5,3 ribu ha. Sedangkan Wilayah Tengah memiliki luas lahan pertanian bukan sawah (terutama kebun dan ladang) yang terluas di Kabupaten Tangerang yaitu 8,6 ribu ha.

Tabel 2 Tataguna Lahan Kabupaten Tangerang tahun 2006 (hektar)

\begin{tabular}{|c|c|c|c|c|c|c|c|}
\hline \multirow[b]{2}{*}{ No } & \multirow[b]{2}{*}{ Wilayah } & \multicolumn{2}{|c|}{ Sawah } & \multirow{2}{*}{$\begin{array}{c}\text { Pertanian } \\
\text { Bukan Sawah }\end{array}$} & \multirow[b]{2}{*}{ Bangunan } & \multirow[b]{2}{*}{ Lain-lain } & \multirow[b]{2}{*}{ Luas Wilayah } \\
\hline & & Irigasi & Bukan Irigasi & & & & \\
\hline & Utara & 17.723 & 3.405 & 4.761 & 7.287 & 897 & 34.073 \\
\hline & Selatan & 37 & 1.392 & 7.494 & 11.968 & 1.300 & 22.191 \\
\hline & Barat & 2.598 & 5.344 & 7.345 & 4.291 & 958 & 20.536 \\
\hline & Tengah & 6.610 & 3.587 & 8.562 & 10.622 & 2.834 & 32.215 \\
\hline & Jumlah & 26.968 & 13.728 & 28.162 & 34.168 & 5.989 & 109.015 \\
\hline
\end{tabular}

Sumber: BPS, 2007 (diolah)

Areal sawah didominasi oleh sawah dengan irigasi teknis, yaitu seluas 26,9 ribu ha, selebihnya adalah lahan sawah bukan irigasi seluas 13,7 ribu ha. Sawah irigasi sebagian besar berada di Wilayah Utara (17,7 ribu ha) dan Tengah (6,6 ribu ha). Dengan demikian kedua wilayah ini berperan strategis dalam penetapan LPA di Kabupaten Tangerang.

\section{Produksi Padi}

Produksi padi Kabupaten Tangerang dihasilkan dari sawah dengan irigasi maupun bukan irigasi. Sebagaimana telah diuraikan di atas, pada tahun 2006 sawah dengan irigasi mencapai luas hampir 27 ribu ha, sedangkan sawah bukan irigasi seluas 13,7 ribu ha. Tabel 3 menyajikan luas sawah, luas panen serta produksi padi Kabupaten Tangerang Tahun 2005 dan 2006.

Tabel 3 Luas lahan, luas panen, dan produksi padi kabupaten Tangerang tahun 2005 dan 2006

\begin{tabular}{|c|c|c|c|c|c|c|c|}
\hline \multirow[b]{2}{*}{ No } & \multirow[b]{2}{*}{ Jenis Sawah } & \multicolumn{3}{|c|}{2005} & \multicolumn{3}{|c|}{2006} \\
\hline & & $\begin{array}{l}\text { Luas Lahan } \\
\text { (ha) }\end{array}$ & $\begin{array}{l}\text { Luas Panen } \\
\text { (ha) }\end{array}$ & $\begin{array}{l}\text { Hasil (ton } \\
\text { GKP) }\end{array}$ & $\begin{array}{l}\text { Luas Lahan } \\
\text { (ha) }\end{array}$ & $\begin{array}{l}\text { Luas Panen } \\
\text { (ha) }\end{array}$ & $\begin{array}{c}\text { Hasil (ton } \\
\text { GKP) }\end{array}$ \\
\hline & Irigasi & 27.041 & 72.492 & 487.871 & 26.968 & 71.501 & 481.987 \\
\hline & Bukan Irigasi & 13.943 & 661 & 3.004 & 13.728 & 802 & 3.656 \\
\hline & Jumlah & 40.984 & 73.153 & 490.875 & 40.696 & 72.303 & 485.643 \\
\hline
\end{tabular}

Sumber: BPS, 2007 (diolah)

Produksi padi Kabupaten Tangerang dalam Tahun 2006 adalah 485 ribu ton GKP (gabah kering panen).Wilayah Utara menjadi pemasok utama produksi padi yaitu sebanyak 248 ribu ton GKP, disusul Wilayah Tengah, Barat dan Selatan masing-masing berturut-turut sebanyak 118 ribu ton GKP, 
103 ribu ton GKP dan 16 ton GKP. Sebagaimana ditunjukkan dalam Tabel 2 di atas, Wilayah Utara memiliki lahan sawah yang paling luas dibandingkan dengan wilayah yang lain di dalam Kabupaten Tangerang. Dalam 2 tahun terakhir, Kabupaten Tangerang mengalami penurunan produksi padi sebanyak 5 ribu ton GKP (gabah kering panen), yaitu dari 490 ribu ton GKP pada tahun 2005 menjadi 485 ton GKP pada tahun 2006. Penurunan produksi padi ini sejalan dengan penurunan luas lahan dan luas panen sawah yang terjadi selama kurun waktu 2005-2006.

\section{Hidrologi dan DAS}

Wilayah Kabupaten Tangerang termasuk dalam DAS (Daerah Aliran Sungai)

Cisadane-Ciliwung, yang juga meliputi wilayah DKI Jakarta, Depok, Bogor dan Bekasi. Daerah hulu DAS Cisadane-Ciliwung sebagian besar berada dalam Wilayah Kabuapaten Bogor, sedangkan Kabupaten Tangerang merupakan daerah hilir dari DAS Cisadane-Ciliwung. Dinamika sumberdaya air dan lahan dalam suatu DAS sangat mempengaruhi produksi pertanian pada daerah yang bersangkutan. Dinamika perkembangan suatu DAS dapat dibedakan dalam 3 (fase) perkembangan DAS, sebagaimana ditunjukkan dalam Gambar 1 di muka. Dalam Gambar 1 tampak bahwa pada Fase Pertama perkembangan DAS, usaha perluasan sawah masih memungkinkan dilakukan untuk meningkatkan produksi pertanian. Pada Fase Kedua mulai tampak kecenderungan penurunan (konversi) lahan pertanian untuk pemukiman. Sedangkan Fase Ketiga perkembangan DAS penggunaan lahan didominasi untuk pemukiman, sedangkan lahan pertanian menjadi semakin berkurang. DAS di Pulau Jawa, termasuk Kabupaten Tangerang sebagian besar berada pada Fase Kedua dan sebagian yang lain berada pada Fase Ketiga dari perkembangan DAS.

Untuk menjamin ketersediaan pangan yang mencukupi seluruh kebutuhan penduduk, maka konversi lahan pertanian harus dicegah melalui penetapan LPA. Di samping itu, sumberdaya air untuk kebutuhan pertanian juga harus dilindungi, mengingat bahwa hampir seluruh produksi padi (lebih dari 99\%) di Kabupaten Tangerang dihasilkan dari sawah irigasi. Untuk itu, diperlukan upaya-upaya meningkatkan kemampuan produksi pertanian, baik melalui pengendalian koversi lahan pertanian maupun melalui perluasan jaringan irigasi di Kabupaten Tangerang. Dalam kaitan ini penetapan suatu kawasan sebagai LPA mutlak diperlukan sebagai prasyarat pembangunan pertanian.

\section{Analisis Indikator dan Identifikasi Parameter}

\section{Kemampuan Lahan}

Dari luas lahan sawah di seluruh Kabupaten Tangerang, baik yang beririgasi maupun bukan irigasi seluas 40.696 ha pada tahun 2006 menghasilkan padi sebanyak 485.643 ton GKP. Dengan luas panen 72.303 ha maka produktivitas rata-rata adalah 6,7 ton GKP per ha (lihat Tabel 3). Paling sedikit terdapat 3 (tiga) desa yang memilki tingkat produktivitas di atas 7,0 ton GKP per ha, yaitu Desa Sukadiri (Wilayah Utara), Sepatan (Wilayah Tengah) dan Pakuhaji (Wilayah Utara), yang keseluruhannya dihasilkan dari sawah beririgasi. Sebagaimana diketahui bahwa kemampuan lahan merupakan hasil dari interaksi sifat fisik dan kimia tanah dengan iklim, serta teknik budidaya tanaman. Diperlukan survei detil untuk seluruh sawah yang berada di Kabupaten Tangerang, sehingga bisa dihasilkan suatu peta kelas kemampuan lahan beserta sub kelas dan satuan pengelolaannya.

Untuk melaksanakan survei tanah secara detil, diprioritaskan pada sawah yang beririgasi yaitu seluas 26.968 ha, karena kontribusinya yang sangat besar dalam produksi padi. Dengan jumlah plot pengambilan sampel sebanyak 20 buah setiap 100 ha, maka dibutuhkan pengambilan sampel sebanyak 5.400 sampel pengamatan. Sedangkan untuk lahan sawah bukan irigasi cukup dilakukan survei semi detil dengan jumlah sampel sebanyak 1.370 buah (10 sampel untuk setiap 100 ha sawah bukan irigasi). 
Selain lahan sawah, di Kabupaten Tangerang terdapat lahan pertanian bukan sawah terutama berupa lahan tegal atau kebun. Pada lahan ini banyak diusahakan untuk tanaman pangan selain padi, seperti jagung dan ubi, kacang tanah, dan berbagai sayuran. Luas lahan pertanian bukan sawah Kabupaten Tangerang tahun 2006 adalah 28.162 ha, yang tersebar hampir merata di seluruh wilayah Kabupaten Tangerang. Untuk kepentingan penetapan LPA, lahan pertanian bukan sawah cukup dilakukan survei tinjauan mendalam dengan pengambilan sampel sebanyak 1.400 buah (5 sampel untuk setiap 100 ha lahan pertanian bukan sawah). Selain survei tanah dengan berbagai tingkatan seperti tersebut diatas, untuk penentuan LPA juga diperlukan pengamatan yang mendalam mengenai iklim, terutama temperatur dan curah hujan. Data mengenai iklim dapat diperoleh dari Stasiun Geofisika Kelas I Tangerang, Badan Meteorologi dan Geofisika (BMG). Data iklim 3 (tiga) tahun terakhir disajikan dalam Tabel 4.

Tabel 4 Temperatur Udara, Kelembaban Udara, Intensitas Matahari, Curah Hujan dan Hari Hujan di Stasiun Geofisika Kelas I Tangerang Tahun 2003-2006

\begin{tabular}{|c|c|c|c|c|c|c|c|}
\hline \multirow[b]{2}{*}{ No } & \multirow[b]{2}{*}{ Tahun } & \multicolumn{2}{|c|}{ Temperatur ( 0 celcius) } & \multirow{2}{*}{$\begin{array}{c}\text { Kelembaban } \\
\text { Udara (\%) }\end{array}$} & \multirow{2}{*}{$\begin{array}{c}\text { Intensitas } \\
\text { Matahari (\%) }\end{array}$} & \multirow{2}{*}{$\begin{array}{l}\text { Curah Hujan } \\
\text { (mm) }\end{array}$} & \multirow{2}{*}{$\begin{array}{c}\text { Hari Hujan } \\
\text { (hari) }\end{array}$} \\
\hline & & Maksimum & Minimum & & & & \\
\hline & & 33,2 & 23,2 & 81,3 & 61,3 & 162,3 & 9,3 \\
\hline & & 32,4 & 23,2 & 81,9 & 58,5 & 165,6 & 11,8 \\
\hline & & 33,7 & 21,5 & 78,0 & 56,8 & 108,4 & 9,3 \\
\hline
\end{tabular}

Sumber: BPS, 2007 (diolah)

Dari Tabel 4 tampak bahwa dalam 3 (tiga) tahun terakhir tidak ditemukan perbedaan iklim yang cukup berarti, kecuali curah hujan rata-rata bulanan tahun 2006 yang paling rendah yaitu 108,4 mm. Suhu terendah juga terjadi pada tahun 2006, meskipun tidak terlalu berbeda jauh dibandingkan tahun sebelumnya yaitu 21,50C. Masih diperlukan pengamatan kondisi iklim yang terus menerus, sehingga dapat digunakan untuk mengatur pola dan rencana tanaman. Pembangunan stasiun pengamatan cuaca di daerah LPA mutlak diperlukan. Sebagaimana diketahui, iklim adalah penghambat utama kemampuan lahan. Didaerah beriklim basah seperti Indonesia, hujan sangat mempengaruhi tingkat erosi yang terjadi. Jumlah curah hujan, intensitas dan distribusi hujan menentukan kekuatan dispersi hujan terhadap tanah, jumlah dan kecepatan aliran permukaan serta kerusakan erosi.

\section{Perubahan Global}

\section{Persaingan Sumberdaya Lahan}

Kabupaten Tangerang secara keseluruhan berada pada fase kedua perkembangan DAS, yang ditandai dengan donimasi kegiatan pertanian dan peningkatan kebutuhan untuk pemukiman. Lahan pertanian di Kabupaten meliputi areal seluas 68.858 ha (63\% dari seluruh luas lahan Kabupaten Tangerang). Konsentrasi lahan pertanian terluas terdapat di Wilayah Utara, yaitu 25.889 ha (76\% dari luas Wilayah Utara).

Pada Wilayah Selatan, fase perkembangan DAS telah memasuki fase ketiga yang didominasi oleh lahan pemukiman seluas 11.968 ha (54\% dari seluruh luas Wilayah Selatan). Wilayah Selatan berbatasan langsung dengan DKI Jakarta, sehingga penduduknya sebagian besar bekerja di DKI Jakarta. Pada Wilayah Selatan ini perluasan pemukiman telah mengkonversi lahan pertanian terutama lahan pertanian bukan sawah. 
Wilayah Tengah memiliki kecenderungan untuk mengikuti Wilayah Selatan dalam memasuki fase ketiga perkembangan DAS. Meskipun lahan pertanian masih mendominasi Wilayah Tengah, akan tetapi dengan tingkat pertumbuhan penduduk sebesar 2,6\% per tahun dan jumlah penduduk mencapai 1.101.077 orang pada tahun 2006, maka kebutuhan terhadap lahan pemukiman juga akan meningkat. Untuk mencegah koversi lahan pertanian yang tidak terkendali, maka penetapan LPA pada Wilayah Tengah perlu diprioritaskan.

\section{Persaingan Sumberdaya Air}

Selain persoalan persaingan sumber daya lahan, Kabupaten Tangerang juga menghadapai persoalan persaingan sumberdaya air. Jika pada tahun 2003 sebagian besar air (71\% dari total air di Kabupaten Tangerang) digunakan untuk kepentingan irigasi, maka pada tahun 2025 diperkirakan air yang tersedia untuk irigasi hanya $44 \%$. Sedangkan sisanya digunakan untuk memenuhi kebutuhan rumah tangga yang semakin banyak, dan juga untuk kebutuhan industri. Sumber air irigasi wilayah Kabupaten Tangerang adalah Sungai Cisadane dan Cidurian. Grafik debit Sungai Cisadane dan Cirudian disajikan dalam Gambar 2. Dari grafik tersebut tampak bahwa debit air yang melaluikedua sungai tersebut cenderung menurun dalam 2 (dua) tahun terakhir. Jika pada tahun 2005 debit tertinggi Sungai Cisadane mencapai lebih dari 130 l/detik, maka debit tertinggi pada tahun 2006 di bawah 100 l/detik.

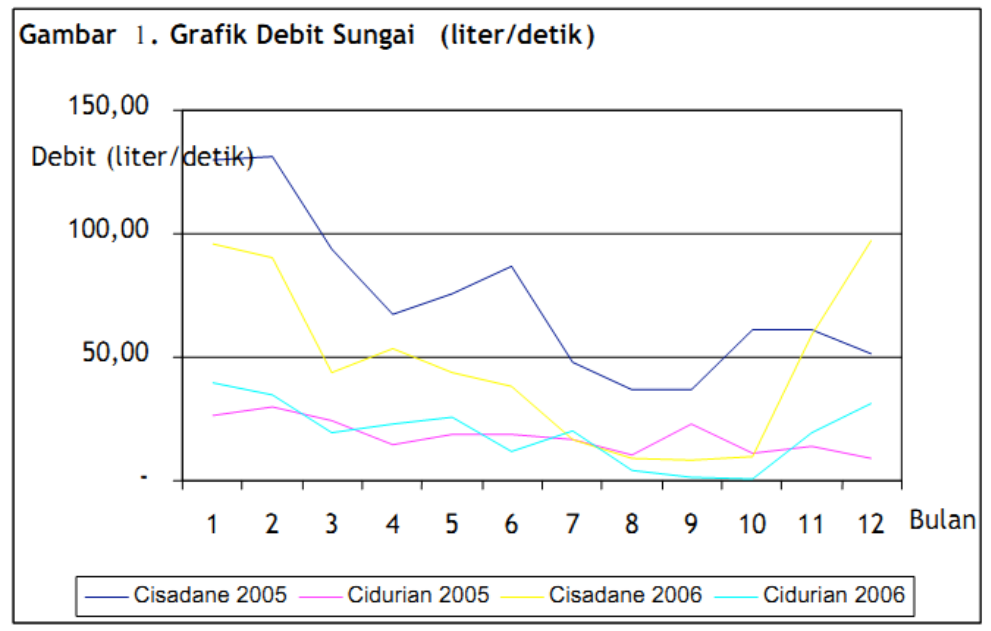

Gambar 1 Grafik debit sungai

Dinas Pertanian dan Peternakan Kabupaten Tangerang telah melakukan peningkatan pemberdayaan sarana dan prasarana irigasi, antara lain: pembangunan dan rehabilitasi saluran tersier, inventarisasi jaringan tersier, serta pembinaan P3A (Perkumpulan Petani Pemakai Air) Mitra Cai. Dalam pengeloaan jaringan irigasi, peran serta masyarakat sangat mendukung tercapainya fungsi irigasi. Melalui pengelolaan irigasi secara berkelompok, diharapkan timbul kepentingan bersama sehingga penggunaan air irigasi dapat dipergilirkan pada suatu musim ataupun antar musim. Selain melibatkan masyarakat dalam pengelolaan air irigasi yang semakin langka untuk pertanian, peran teknologi juga sangat membantu efisiensi air irigasi. Teknologi komputer dapat digunakan untuk secara otomatis mengatur presisi suplai air. Pada tahap ini, pengelolaan air irigasi telah bekerja berdasarkan sistem pasar, yaitu apabila komoditi yang diusahakan memberikan keuntungan yang besar dan diperlukan efisiensi yang tinggi serta pemberian air yang tepat waktu. 


\section{Perubahan Iklim dan Lingkungan}

Diperlukan seri data yang sangat panjang untuk mengetahui dan memprediksi pengaruh perubahan iklim dan lingkungan terhadap produksi pertanian di Kabupaten Tangerang. Stasiun pengamatan cuaca yang dibangun di wilayah LPA dapat menyediakan untuk kepentingan ini. Berbagai data yang diperlukan antara lain: kedalaman air tanah, temperatur permukaan bumi, dan untuk sebagian Wilayah Utara yang berbatasan dengan pantai, pengamatan terhadap fluktuasi pasang surut air laut, serta interusi air laut.

Potensi LPA terutama dengan tanaman padi yang menggunakan air dan pupuk nitrogen secara berlebihan dalam menghasilkan gas metan perlu dikendalikan dengan cermat. Gas metana dalah perusak lapisan ozon yang pada akhirnya menyebabkan pemanasan global. Dalam penetapan LPA di Kabupaten Tangerang, lahan sawah harus dikelola dengan memperhatikan efisiensi air irigasi dan penggunaan pupuk secara bijaksana. Dalam kaitan ini, pengaturan pola tanam dan pergiliran tanaman yang berwawasan lingkungan mutlak dilakukan.

Ketrampilan petani dalam mengenal faktor iklim dan lingkungan untuk keberhasilan usaha tani harus senantiasa ditingkatkan. Para petani harus terbiasa mengamati arah angin, suhu udara, curah hujan dalam jangka waktu tertentu, dan mampu memprediksikan cuaca pada waktu mendatang, sehingga pola tanam yang cocok dengan cuaca dapat diterapkan. Dengan demikian, kesalahan waktutanam karena ketidakcocokan dengan musim, seperti banjir atau kekeringan dapat dihindarkan.

\section{Ketahanan Pangan}

Dari total produksi padi Kabupaten Tangerang Tahun 2006 (lihat Tabel 3) sebanyak 485.643 ton GKP, setelah dikurangi untuk kebutuhan benih, pakan ternak dan tercecer, akan dihasilkan produksi netto ketersediaan padi untuk konsumsi pangan sebanyak 445.432 ton GKP. Dengan faktor konversi 0,632 (atau 63,2\%), maka dari produksi netto ketersediaan padi sebanyak 445.432 ton GKP tersebut, akan dihasilkan produksi netto beras sebanyak 281.513 ton.

Perhitungan rasio konsumsi pangan Kabupaten Tangerang disajikan dalam Tabel 5. Wilayah Utara merupakan daerah utama penghasil beras bagi Kabupaten Tangerang yaitu sebanyak 143.855 ton. Sedangkan Wilayah Selatan menghasilkan beras yang paling sedikit yaitu hanya sebanyak 9.539 ton selama tahun 2006.

Tabel 5 Perhitungan rasio konsumsi dan Surplus (defisit) beras 2006

\begin{tabular}{lrrrrrr}
\hline No Wilayah & $\begin{array}{r}\text { Hasil Padi } \\
\text { (ton GKP) }\end{array}$ & Beras (ton) & $\begin{array}{c}\text { Jumlah } \\
\text { Penduduk } \\
\text { (orang) }\end{array}$ & $\begin{array}{c}\text { Kebutuhan } \\
\text { Beras (ton) }\end{array}$ & $\begin{array}{c}\text { Rasio } \\
\text { Konsumsi }\end{array}$ & Surplus (Defisit) \\
\hline 1 Utara & 248.167 & 143.855 & 700.417 & 76.696 & 0,53 & 67.159 \\
2 Selatan & 16.456 & 9.539 & 1.155 .333 & 126.509 & 13,26 & $(116.970)$ \\
3 Barat & 102.516 & 59.425 & 478.378 & 52.382 & 0,88 & 7.043 \\
4 Tengah & 118.504 & 68.693 & 1.101 .077 & 120.568 & 1,76 & $(51.875)$ \\
\cline { 2 - 8 } Jumlah & 485.643 & 281.513 & 3.435 .205 & 376.155 & 0,77 & $(94.642)$ \\
\hline \hline
\end{tabular}

Sumber: BPS, 2007 (diolah)

Jumlah penduduk Kabupaten Tangerang tahun 2006 adalah 3.435.305 orang. Dengan tingkat konsumsi beras sebanyak $300 \mathrm{gr} /$ orang/hari, maka tingkat konsumsi beras penduduk Kabupaten Tangerang adalah 376.155 ton/tahun. Konsumen beras terbesar di Kabupaten Tangerang adalah penduduk Wilayah Selatan dan Tengah. Kedua wilayah ini membutuhkan beras sebanyak 247.077 ton (66\% dari seluruh konsumsi beras Kabupaten Tangerang). 
Secara keseluruhan, Kabupaten Tangerang mengalami defisit beras sebanyak 94.642 ton pada tahun 2006, yaitu dari total produksi beras sebanyak 281.513 ton, kebutuhan konsumsi berasnya sebanyak 376.155 ton. Defisit paling besar dialami Wilayah Selatan yaitu dari kebutuhan beras sebanyak 126.509 ton, hanya menghasilkan beras sebanyak 16.456 ton atau mengalami defisit sebanyak 116.970 ton. Wilayah Tengah juga mengalami defisit beras, meskipun tidak sebesar Wilayah Selatan.

Dengan tingkat pertumbuhan penduduk mencapai 2,44\% per tahun, angka defisit pangan di Kabupaten Tangerang diperkirakan akan semakin membesar. Jika ketahanan pangan menjadi tujuan pembangunan pertanian di Kabupaten Tangerang, maka penetapan LPA mendesak dilakukan. Bahkan dengan tingkat pertumbuhan penduduk yang sangat tinggi tersebut, penetapan LPA saja tidak mencukupi untuk memenuhi kebutuhan pangan. Diperlukan strategi intensifikasi dan ekstensifikasi lahan pertanian, sehingga laju peningkatan produksi dapat melebihi laju peningkatan konsumi pangan terutama beras. Untuk itu penetapan LPA harus juga pada lokasi yang memiliki daya dukung yang tinggi untuk mencapai tingkat produktivitas yang diinginkan.

\section{Lahan Pertanian Abadi}

\section{Mempertahankan Kondisi Sekarang}

Seluruh lahan dalam LPA harus diinventarisasi ulang, sehingga dapat dibuatkan tata batas luar yang permanen berupa pal tata batas. Sebuah tim terpadu diperlukan untuk melaksanakan survei tata batas ini. Rancangan awal LPA Kabupaten Tangerang dimulai dari mempertahankan seluruh lahan sawah beririgasi yang sekarang ada di Wilayah Utara, Tengah dan Barat. Lahan sawah bukan irigasi menjadi prioritas berikutnya untuk ditetapkan sebagai LPA. Lahan sawah bukan irigasi menyebar secara merata di Kabupaten Tangerang. Sebagian besar merupakan sawah tadah hujan. Dalam penetapan LPA, lahan sawah bukan irigasi difungsikan sebagai lahan cadangan untuk perluasan lahan sawah irigasi.

LPA tidak lengkap jika tidak memasukkan lahan pertanian bukan sawah yang sangat penting dalam produksi palawija dan hortikultura. Lahan pertanian bukan sawah di Kabupaten Tangerang lebih besar dibandingkan lahan sawah bukan irigasi. Lahan pertanian ini paling rentan terhadap proses konversi untuk penggunaan bukan pertanian. Hal ini disebabkan lahan sawah bukan pertanian umumnya berdekatan dengan pemukiman yang telah ada, sehingga proses konversi untuk pemukiman tidak memerlukan biaya yang sangat tinggi untuk pembangunan infrastrukturnya. Di dalam LPA, komponen penghasil palawija dan hortikultura harus diletakkan berdampingan dengan lahan sawah sebagai penghasil tanaman pangan.

Berdasarkan lampiran peta dalam PERDA Tataruang Kabupaten Tangerang, identifikasi wilayah LPA disajikan dalam peta pada Lampiran. Potensi LPA Kabupaten Tangerang meliputi areal seluas 68.858 ha, yang terdiri dari 26.968 ha lahan sawah irigasi, 13.728 ha lahan sawah bukan irigasi, serta 28.162 ha lahan pertanian bukan sawah. Jika seluruh potensi ini dapat dimaksimalkan, maka LPA akan menjamin ketahanan pangan Kabupaten Tangerang dalam jangka waktu yang cukup panjang.

\section{Strategi Intensifikasi dan Ekstensifikasi}

\section{Strategi Intensifikasi}

Strategi intensifikasi ditujukan untuk meningkatkan produktivitas lahan pertanian. Strategi intensifikasi dibatasi oleh kemampuan (daya dukung) lahan dan tingkat teknologi yang dapat diadopsi oleh petani. Berdasarkan survei detil lahan, tingkat produktivitas optimum yang dapat dicapai dengan teknologi yang tersedia, dapat mulai disebarluaskan kepada para petani. 
Pemerintah memiliki peran strategis dalam strategi intensifikasi pertanian ini. Investasi pembangunan jaringan irigasi, penyediaan tenaga pendamping (terutama penyuluh pertanian), serta sistem distribusi sarana produksi pertanian (seperti pupuk dan pestisida) dan jaringan pemasaran hasil, menjadi kewajiban pemerintah untuk menyediakannya. Jika mekanisme pasar mulai berjalan, peran pemerintah dalam penyediaan berbagai sarana dan prasarana ini dapat semakin berkurang, sehingga pada akhirnya akan sepenuhnya diserahkan kepada mekanisme pasar.

Strategi intensifikasi pertanian juga harus memperhatikan dampak lingkungan, sebagai akibat penggunaan pupuk dan pestisida secara berlebihan. Efisiensi pemakaian air irigasi dapat dicapai melalui pergiliran penggunaan air irigasi, maupun pemakaian ulang air irigasi yang telah terpakai. Teknologi komputer dapat digunakan untuk secara otomatis mengatur presisi suplai air irigasi. Strategi intensifikasi pertanian sekaligus juga membagi wilayah LPA berdasarkan komoditas unggulan yang sesuai dengan kemampuan lahan. Pengaturan pola dan pergiliran tanaman menjadi kunci keberhasilan membangun LPA berdasarkan komoditas unggulan. Sekali lagi, survei detil lahan akan sangat menentukan engelolaan LPA berkaitan dengan pemilihan komoditas unggulan yang akan diusahakan.

\section{Strategi Ekstensifikasi}

Strategi ekstensifikasi di dalam wilayah LPA difokuskan pada perluasan lahan sawah beririgasi. LPA Kabupaten Tangerang terdiri atas lahan sawah beririgasi, lahan sawah bukan irigasi, serta lahan pertanian bukan sawah. Perluasan lahan sawah beririgasi dilakukan dengan membangun jaringan irigasi pada lahan sawah bukan irigasi. Pemanfaatan air tanah untuk irigasi lahan sawah bukan irigasi, juga menjadi bagian strategi ekstensifikasi ini. Ekstensifikasi lahan sawah irigasi tidak harus dilakukan dengan pencetakan sawah baru. Lebih diutamakan meningkatkan lahan sawah bukan irigasi menjadi lahan sawah beririgasi, dengan alasan efisiensi dan efektifitas anggaran pembangunan. Pada areal bukaan baru, investasi yang diperlukan jauh lebih tinggi, terutama dalam pembangunan sarana dan prasarana irigasi dan transportasi.

Ekstensifikasi dalam arti perluasan lahan pertanian di luar LPA sebagaimana tersebut di atas, juga menghadapi kendala terbatasnya lahan di Kabupaten Tangerang. Hampir seluruh lahan di Kabupaten Tangerang telah berfungsi sesuai peruntukannya. Kebutuhan lahan pemukiman yang meningkat akibat perkembangan jumlah penduduk juga menjadi kendala utama dalam strategi ekstensifikasi ini. Dari data dalam Tabel 2 terdapat lahan dengan penggunaan lain-lain seluas 5.989 ha, yang perlu diidentifikasi dengan lebih detil untuk memenuhi ekstensifikasi di luar LPA. Jika memungkinkan, strategi ekstensifikasi di luar LPA ini hanya dilakukan dalam keadaan mendesak, manakala tujuan utama penetapan LPA, yaitu menciptakan ketahanan pangan, tidak dapat tercapai dengan LPA yang tersedia.

\section{SIMPULAN}

\section{Simpulan}

Simpulan yang didapatkan dari penelitian ini, yaitu penetapan LPA di Kabupaten Tangerang harus memenuhi 3 (tiga) indikator, yaitu kemampuan lahan, indikator perubahan global, dan indikator ketahanan pangan. Perwilayahan di dalam suatu LPA ditentukan berdasarkan sumberdaya air yang dimiliki, yaitu lahan sawah beririgasi, lahan sawah bukan irigasi, dan lahan pertanian bukan sawah. Untuk memberikan batas yang jelas antar wilayah LPA dengan lingkungan sekitarnya, perlu dilakukan tata batas luar berupa patok permanen. Pengelolaan LPA ditentukan berdasarkan survei kemampuan lahan sesuai dengan perwilayahan LPA, yaitu survei detil untuk lahan sawah beririgasi, survei semi detil untuk lahan sawah bukan irigasi, dan survei tinjauan mendalam untuk lahan pertanian bukan sawah. Untuk memperoleh hasil optimum dari LPA, strategi intensifikasi dan ekstensifikasi dapat dilakukan sesuai kemampuan lahan berdasarkan survei lahan yang telah dilakukan sebelumnya. 


\section{Saran}

Saran untuk penelitian selanjutnya yaitu: (1) segera lakukan survei (penelitian) kemampuan lahan untuk menetapkan LPA sesuai jenis perwilayahan LPA; (2) keseluruhan survei tersebut, harus dapat merekomendasikan luas dan lokasi LPA, sarana dan prasarana yang diperlukan, serta sistem tekonologi dan pengelolaan yang diterapkan, sehingga menghasilkan tingkat produksi yang optimum.

\section{DAFTAR PUSTAKA}

Biro Pusat Statistik (BPS). (2007). Kabupaten Tangerang dalam Angka 2006. Kabupaten Tangerang: BPS.

Dinas Pertanian dan Peternakan Kabupaten Tangerang. (2006). Laporan Analisis Ketersediaan Pangan di Kabupaten Tangerang.

Kabupaten Daerah Tingkat II Tangerang. (1996). Peraturan Daerah Kabupaten Tangerang No. 5 Tahun 2002 Tentang Perubahan atas PERDA Kabupaten Daerah Tingkat II Tangerang No. 3 Tahun 1996 tentang RTRW.

Pemda Kabupaten Tangerang. (2007). Laporan Keterangan Pertanggungjawaban Akhir Masa Jabatan Kepala Daerah Kepada DPRD Kabupaten Tangerang Tahun 2003-2008. 